\title{
Affects and Activity in Leibniz's De Affectibus
}

\section{Roinila, Markku}

Springer

2015-07-01

Roinila , M 2015 , Affects and Activity in Leibniz's De Affectibus . in A Nita (ed.), Leibniz's metaphysics and adoption of substantial forms . Springer , Dordrecht , pp. 73-88 . https://doi.org/10.1007/978-94-01

http://hdl.handle.net/10138/182576

https://doi.org/10.1007/978-94-017-9956-0_6

cc_by

acceptedVersion

Downloaded from Helda, University of Helsinki institutional repository.

This is an electronic reprint of the original article.

This reprint may differ from the original in pagination and typographic detail.

Please cite the original version. 


\section{Affects and Activity in Leibniz's De Affectibus}

Markku Roinila

Postprint

\section{Abstract}

In this paper I will discuss the doctrine of substance which emerges from Leibniz's unpublished early memoir De affectibus of 1679. The memoir marks a new stage in Leibniz's views of the mind. The motivation for this change can be found in Leibniz's rejection of the Cartesian theory of passion and action in the 1670s. His early Aristotelianism and some features of Cartesianism persisted to which Leibniz added influences from Hobbes and Spinoza. His nascent dynamical concept of substance is seemingly a combination of old and fresh influences, representing a characteristically eclectic approach, but I will argue that the influence of Hobbes is especially important in the memoir. To do that, I will examine Leibniz's development in the 1670s up to the De affectibus and consider the nature of affects in the memoir, especially the first affect which starts the thought sequence. This first affect of pleasure or pain is the key to Leibniz's theory of active substances and in this way to the whole of Leibniz's moral psychology and ethical metaphysics.

$$
* * *
$$

The topic of this paper is the doctrine of substance which emerges from Leibniz's unpublished early memoir De affectibus of 1679 (A VI, 4, 1410-1441). It is unclear why Leibniz wrote the memoir in the first place, but lately it has gained increasing attention as an early formulation of his metaphysical dynamism. ${ }^{1}$ While the first half of the text deals mostly with the contents of Descartes's Les passions de l'ame (1649), the second half discusses philosophy of mind and metaphysics of emotions and I will concentrate on that latter half of the text.

De Affectibus marks a new stage in Leibniz's views of the mind. The motivation for this change can perhaps be found in Leibniz's rejection of the Cartesian theory of passion and

\footnotetext{
${ }^{1}$ Schepers $(2003,133-135)$ speculates that by analysing Descartes's and Spinoza's views on passions or affections Leibniz sought to find material for his planned scientia generalis. Di Bella argues along the same lines $(2006,194)$. As I will argue later, I think Leibniz saw affections as important in his moral philosophy, as Elementa juris naturalis of 1671 already shows. Therefore I think that his interest in passions was fired up by the need to explain human behavior in general. In the previous year he also read and copied passages from Spinoza's Ethica, parts III-V, noting in his letter to Vincent Placcius of 14. February 1678 that Spinoza had said many good things about the affects (A II, 1, 593).
} 
action in the 1670s. His early Aristotelianism and some features of Cartesianism persisted to which Leibniz added influences from Hobbes and Spinoza. His nascent dynamical concept of substance is seemingly a combination of old and fresh influences, representing a characteristically eclectic approach. I will examine Leibniz's development in the 1670s up to the De affectibus and consider the nature of affects in the memoir, especially the first affect which starts the thought sequence. This first affect is the key to Leibniz's theory of active substances and in this way it is key to the whole of Leibniz's moral psychology and ethical metaphysics.

\section{Background}

Leibniz was taught traditional Aristotelianism in his university years, but at an early age he decided to follow the mechanistic philosophy of the moderns such as Descartes, Gassendi and Hobbes. Characteristically he was not quite happy with all the aspects of their philosophy and tried to reconcile between the best parts of their systems (Garber 2009a, 5-9). In addition, not wanting to part ways with Aristotelianism, he wanted to have a teleological conception of substance, that is, he wished to preserve the Aristotelian doctrine of forms despite the ardent opposition of the mechanists. ${ }^{2}$

According to Aristotle, active powers enable whatever has them to transmit new forms to substances possessing the passive power to receive those forms (Schneewind 2006, 559). ${ }^{3}$ The conception of metaphysical powers changed in the Early Modern period: they are analysed as secondary qualities like colours, tastes or smells, which result from our interaction with the world and reduced to only two, action and passion (James 1997, 85).

This is central in Descartes's view. In the Cartesian picture the soul has only one part and possesses one power, the power of thinking. ${ }^{4}$ Although willing and understanding occur in the soul alone, sensory perceptions, passions, some memories and some fantasies depend on the interaction of soul and body. In Les passions de l'âme (1649), §17 he says:

There is nothing in us which we must attribute to our soul except our thoughts. These are of two principal kinds, some being actions of the soul and others its passions. Those I call its actions are all our volitions...the various perceptions or modes of knowledge present in us may be called its passions in the general sense, for it is often not our soul which makes them

\footnotetext{
${ }^{2}$ See, for example, Discours de metaphysique, $\S 10$.

${ }^{3}$ Active powers are potentialities, which are external principles of change or being at rest (Metaphysics 9. 8, 1049b5-10). Thus they are essential in explaining causes.

${ }^{4}$ On the nature of the soul, see Second Meditation, CSM II, 19-20.
} 
such as they are, and the soul always receives them from the things that are represented by them (CSM I, 335).

Passions in one sense are all the functions of the soul that are not actions of the soul or volitions (Passions, §28; CSM I, 339). Action and passion are essential in Descartes' theory of mind-body interaction which takes place through the pineal gland and the movements of the animal spirits (Passions, §30-37; CSM I, 339-342). Emotions typically have bodily manifestations (shame causes blushing etc.) and this is why they cannot be restricted to the soul alone.

Descartes makes a considerable effort at explaining the passions with the movements of the animal spirits (Passions, §160; CSM I, 386-387), but there is a serious problem in the mindbody interaction which was famously pointed out by Princess Elisabeth, namely, how can a mental soul affect the material body? (Elisabeth's letter to Descartes 6. May 1643, Shapiro $(2007,62))$. This problem affects the theory of action and passion in the sense that passions seem to be complex interpretations (of immanent danger, for example) and thus fruits of judgements and inferences in the soul rather than a flow of animal spirits (James 1997, 104105). Thus ascribing action to the soul and passion to the body seems to be problematic as the active soul apparently has no direct way to affect the passive body.

Like Malebranche, Leibniz could not accept the soul/body-divide of Descartes because of these problems and his criticism towards Cartesianism increased in his formative period of 1672-76 when he was on a diplomatic mission to Paris. ${ }^{5}$ However, he retained some features of Cartesianism in his later philosophy, as we will soon see. During the Paris years Leibniz was also reflecting on metaphysics, writing, among others, a collection of short notes and memoirs now known as De summa rerum (1675-76, A VI, 3, 461-588). One topic essential to developing his metaphysics was the nature of substance and the question of activity versus passivity. After rejecting most of the Cartesian doctrine he played for a short time with Spinozian monism, but in the end he devised a pluralist metaphysics with an infinite number of substances. As a consequence, Leibniz had to develop a new understanding of activity and passivity. De affectibus is one of his earliest attempts to do that.

\section{The Memoir}

De affectibus, which remained unpublished, was written in April 1679, a few years after Leibniz had settled at the Hannover court following his stay in Paris. Before that he had

\footnotetext{
${ }^{5}$ On Malebranche's criticism of Descartes's views, see James (1997, 108-123). On Leibniz's intellectual development in the Paris years, see Antognazza (2008, 139-192) and Mercer (2001, 385-461).
} 
carefully read Spinoza's Opera posthuma in 1678 and found that he could not accept many of its central doctrines. The memoir, which can be characterized as working notes (Jones 2006, 250), begins with a collection of definitions and reflections on Descartes' theory of the passions. Before writing this piece, he had read Les passions de l'âme the previous year and briefly copied some parts of it with marginal notes and some underlinings (A VI, 4, 1703-05). Of interest is the fact that many points Leibniz wrote down from Descartes' work concern the details of the mind-body union, such as the movement of the pineal gland, the movement of the animal spirits, and of how certain passions such as love and joy arise from the movement of the spirits. ${ }^{6}$

The series of definitions in several groups seem at first to be random, having no relation to each other and composing no apparent unity, although the first half of the text loosely follows the structure of the Passions. Most definitions concern single affects or characteristics of man such as honour, wonder, curiosity, diligence, cupidity etc. (A VI, 4, 1414-1416). They seem to be short summaries or reformulations of the ones in Descartes' Passions as some definitions refer to articles of that work. In addition, the text includes a long section of definitions of passions copied from Descartes's work. Thus the first three sections seem to be a collection of Cartesian and original alternative definitions of passions. ${ }^{7}$

In section $\mathrm{D}^{8}$ the tone of the text changes and we are provided with reflections on affects and how they influence our actions. While passions and affects are usually thought to be two names for the same thing, it is noteworthy that after ceasing to refer to Descartes, Leibniz systematically uses the term 'affect', familiar especially from Spinoza's writings. One gets the impression that Leibniz turns from the Cartesian theory of passions to Spinoza's theory of affects although it is noteworthy that De affectibus discusses only affects of the mind, not of the body. Alluding to Aristotelianism, Leibniz explicitly says that what affect is in the mind, impetus is in the body (A VI, 4, 1426). Some emotions are also discussed within this new kind of framework. Finally, from section H Leibniz turns to metaphysics proper, discussing potentiality, perfection and determination. The text seems to have more backbone and systematicity. ${ }^{9}$ Eventually all the previous themes are incorporated in the doctrine of thought sequences which are initiated with affects. The essential question seems to be: how are the following states of the soul determined, or what brings about change in the substance?

\footnotetext{
${ }^{6}$ Leibniz wrote a marginal note on the relationship between love and joy (A VI, 4, 1704). In 1671 he had discussed the essence of pure love in Elementa juris naturalis (A VI, 1, 431-485).

${ }^{7}$ See especially his own definitions in A VI, 4, 1426.

${ }^{8}$ The division A-J is made by the Academy editors. See A VI, 4, 1410.

${ }^{9}$ Schepers finds in the last sections of De affectibus a logical structure. See Schepers (2003), especially $152-$ 160. See also Di Bella $(2006,194)$.
} 


\section{Cartesian and Leibnizian Passions}

One can interpret De affectibus as a remake of Descartes's Les passions de l'âme (Di Bella 2005, 99), but this would apply mostly to the first half of the text. It seems that he was just collecting what he saw as worthwhile in the Passions in order to utilize them in his new understanding of activity and passivity. If this is true, the foremost motivation of the text appears to be metaphysical. While Descartes argues that he is treating the passions only as a natural philosopher (CSM I, 327), that is, to analyse passions and their causes and see how they can be remedied, Leibniz's goal seems to be to place activity and passivity within a framework of plurality of substances. One gets the impression that when he picks up steam, he is not really interested in affects per se, but rather in how they motivate the mind. In fact, it would seem that for Leibniz, whatever brings about a change in the mind, can be called an affect.

It is revealing that also in Leibniz's mature theory of emotions in Nouveaux essais sur l'entendement humain II, $\mathrm{xx}(1704)$, the most important passions are the same as in De affectibus, the ones which have to do with activity and perfection, that is, joy, hope and love (A VI, 6, 162-168). However, it is also true that Leibniz's later conception of passions are essentially tied to metaphysics in the sense that they either produce pleasure or displeasure of the mind and are in that sense related to universal perfection and imperfection.

In De affectibus a central motivation is to explain how the states of the mind follow from one another. According to Vargas $(2011,178)$, by April 1679 Leibniz had already formed the doctrine of expression, but was still uncertain as to how the mind passes from one thought to another. That is why in De affectibus he seeks to explain how affections, understood as actions and passions, are produced in the mind.

Leibniz starts the memoir by distancing passions from corporeality. Both action and passion belong to the mind: passion is some state which is the proximate effect of change while action is some state which is the proximate cause of change. ${ }^{10}$ Later in the memoir he says: "An action is the state of a thing according to which something does follow, arising from its nature ... A passion is the state of a thing, according to which something is prevented from following from its nature." in the mind, not their corporeal nature. Sensations of the body such as hunger thus does not

\footnotetext{
10 "Passio est status aliquis qui causa proxima mutationis est" (A VI, 4, 1411). In much later Monadologie of 1714 Leibniz argues in $\$ 49-52$ that mutual action and passion among substances is regulated by the preestablished harmony. In De affectibus Leibniz discusses in terms of individual minds which are either spontaneous in the sense that they are active or the opposite case.

${ }^{11}$ A VI, 4, 1428-1429; translated in Di Bella (2006, 113).
} 
qualify as an affect. ${ }^{12}$

In De affectibus Leibniz defines affect as an occupation or thought of the soul which arises out of its opinion on good and evil. ${ }^{13}$ The source of the affect is a feeling of pleasure or pain which correspond to our opinion on goodness or evil in the situation. In itself, this is an Aristotelian notion - we automatically follow the apparent good - but Goldenbaum (2009, 199) argues persuasively that Leibniz actually took the doctrine from Hobbes's De corpore (1655) or De homine (1658). ${ }^{14}$ In De affectibus Leibniz relates the thinking of good to several other emotions such as love, hope and joy and also to greed and probability of favourable outcome (A VI, 4, 1426).

Related to the opinion on good and evil is the will because Leibniz defines opinion as a volition which follows from an understanding or intellection. ${ }^{15}$ The occupation of the soul is an inclination towards something and because volition is involved, the inclination is toward something which is preferred by the understanding. ${ }^{16}$ One might say that volition cannot arise without thought and thought cannot arise without reason (Giolito 1996, 197). As Leibniz regards the will as an intellectual appetite in the soul, his conception of it is clearly much closer to Thomas Aquinas or even Descartes than to Hobbes for whom the will is the last desire in deliberation. ${ }^{17}$

It is clear that Leibniz does not relate affects to external objects as Descartes does (Passions, §53-56; CSM I, 350). They seem to be inherent, occasioned by the sentiment of the soul - that is, the external objects as representational content give occasion to an affect, but are not directly the cause of them in the same way as in Descartes. Leibniz does say that the affection of the mind involves the existence of its objects, but does not really give an argument for establishing the external objects (Vargas 2011, 179). The affect disposes us to incline into a certain direction which is preferred. It carries, as it were, the soul from one reason to another (Giolito 1996, 197-198). In this way it is much more lasting than a mechanical cause.

In order to see how Leibniz ended up in this position, it is useful to look at his earlier writings in the 1670s. Influenced heavily by Hobbes, in Theoria motus abstracti of 1671 he

\footnotetext{
${ }^{12}$ Compare Passions, $\$ 24$ (CSM I, 337). Referring to $\$ 27-28$, Leibniz argues that affects are perceptions which are related to the soul and not to the body (A VI, 4, 1418). See also Giolito $(1996,198)$.

13 "Affectus est occupatio animi orta ex sententia animi circa bonum et malum" (A VI, 4, 1412).

${ }^{14}$ For another account on Hobbes's influence to Leibniz's early thought, see McDonald Ross (2007, 20 and $24-$

27). I will return to the details of Hobbes' influence to Leibniz in the next section.

15 "Sententia est intellectio ex qua sequitur voluntas" (A VI, 1412).

16 "Occupatio animi est inclinatio ad aliquid prae alio cogitandum" (A VI, 1412).

${ }^{17}$ Hobbes, Leviathan, ch. 6 (1651). At this point Leibniz did not yet have the doctrine of innate instinct of the New Essays (I, ii) where we automatically strive for good or pleasure and avoid evil or imperfection.
} 
stated that every body in collision transfers to the other a conatus equal to its own without thereby losing any of its original conatus. The multiple conatuses last only for a moment before they are resolved into one (A VI, 2, 265-266). ${ }^{18}$ If they are unequal, the resultant conatus will retain the direction of the greatest one, and have for its magnitude the difference between the original conatuses (A VI, 2, 269-70). ${ }^{19}$ If the conatuses are equal, they rule each other out and another one takes their place. Interesting to our purposes is the fact that Leibniz argued that "every body is a momentary mind, or one lacking recollection, because it does not retain its own conatus and the other contrary one together for longer than a moment" (A VI, 2, 266; Leibniz $(1976,141){ }^{20}$

The difference between the mind and the body is that the latter lacks thought and memory which makes it unable to perceive its own actions and passions (A VI, 2, 266). To quote Di Bella, Leibniz was trying to complete the Hobbesian philosophy of body through a new philosophy of mind (Di Bella 2005, 62). This is implicit already in his letter to Hobbes of July 1670 , where he laments that Hobbes had failed to see the proper significance of the conatus for a true theory of the soul (A II, 1, 58). ${ }^{21}$

In De Summa rerum of 1675-1676 Leibniz argues that the solidity or unity of the body comes from the mind and there are as many minds as vortices and as many vortices as solid bodies (Garber 1998, 781). ${ }^{22}$ At this stage Leibniz still holds on to the Cartesian doctrine of extension, but it is implicit that minds are incorporeal substances (Di Bella 2005, 67). ${ }^{23} \mathrm{He}$ thought that the mind is necessarily added to the matter and this seems to be his view also in De affectibus.

Another interesting predecessor to De affectibus is 1673 dialogue Confessio philosophi where Leibniz argues, much the same way as in his later Nouveaux essais that happiness consists of pleasure of the mind and that being delighted is nothing other than experiencing harmony and the greatest harmony consists of thinking of the universe or God. Thus pleasure is the first step towards happiness as all happiness is harmonious (Leibniz 2005, 30-31). Put otherwise, pleasure or judging something to be good is an affect which motivates us to strive for harmony. Interestingly, in this text Leibniz does not discuss the will in the human soul as

\footnotetext{
${ }^{18}$ On Hobbes' influence to TMA, see Wilson (1997, 341-343) and Garber (2009a, 15-17).

${ }^{19}$ See also Garber (2009a, 17-18).

$20 \mathrm{The}$ doctrine of perceiving bodies is also a debt Leibniz owes to Hobbes. See MacDonald Ross (1997, 27-30).

${ }^{21}$ See also Boros $(2007,82-83)$ and Wilson $(1997,344)$. In his letter to Arnauld in 1671 Leibniz said that the philosophy of motion is a step towards the science of the mind (A II, 1, 278). On Leibniz's early attempts to formulate such a science, see Busche (2004, 142-151).

${ }^{22}$ See also Wilson (1997, 343-344).

${ }^{23}$ See also Leibniz (1992, xlv).
} 
in De affectibus. It is said that what a conatus is in a body, an affect is in the mind - thus Leibniz held on to the Hobbesian idea of bodies as momentary minds. ${ }^{24}$ However, it must be noted that Leibniz explained to Arnauld two years earlier, in 1671, that the conatus of the mind is the will (A II, 1, 173). ${ }^{25}$

The will as a part of the soul returns to the picture in Elementa verae pietatis of $1677-78^{26}$ where Leibniz characterized it as a sentiment concerning good and evil. Sentiment, again, is characterized as a practical thought, that is, a thought with a tendency (conatus) toward action (Leibniz 2005, 161). Here the idea of an occupation of the soul as a tendency which is related to our opinions of good and evil is already in place. What De affectibus introduces is the dynamism and teleology of thought sequences.

\section{Affects and Thought Sequences}

The second half of the De affectibus departs clearly from the Cartesian framework. Leibniz discusses a series of thoughts (series cogitationum) which is a continuous series of ideas in the mind. The view is related to the infinite analysis where only God is able to see everything in the series as Leibniz noted in the end of De affectibus and in another memoir titled De libertate around the same time, where he says:

It is easily seen from a consideration of the nature of demonstration and analysis that there can and must be truths which cannot be reduced by any analysis to identities or to the principle of contradiction but which involve an infinite series of reasons which only God can see through (Leibniz 1971, 185; Leibniz 1976, 266).

While in his earlier works Leibniz had argued that pleasure and pain are related to experiencing harmony, here he presents the series of thoughts as a law-like process or ordered progress of thoughts in the mind which has its origin in the affect of pleasure or pain. ${ }^{27}$ Although the series of thoughts might seem like a mechanical one, the difference is in the continuity - while in mechanics the cause determines the next state, in the mind the sequence lasts a long time and leads to series of changes. Because the first affect is intentional (concerning some good or evil which is sought for), the whole series of thoughts is teleological. The sequence continues until the desired good or evil is reached or found to be unreachable (Di Bella 2005, 100-101). The process can be quite intense and Leibniz

\footnotetext{
${ }^{24}$ This view is also present in Theoria motus abstracti, written in the same year. See Busche (2004, 151-153). Compare also De affectibus (A VI, 4, 1426).

${ }^{25}$ See also Leibniz (2005, 161, n. 101).

${ }^{26}$ Elementa verae pietatis, sive de amore Dei super omnia (A VI, 4, 1357-1366).

27 "Series est multitudo cum ordinis regula" (A VI, 4, 1426). See also A VI, 1424.
} 
compares its ending to waking up from a dream (A VI, 4, 1425-1426). ${ }^{28}$ Different series can also rival each other and we can abandon one series in order to follow another (A VI, 4, 1424).

The determination of the series does not happen mechanically, but by some kind of power or force. At the time Leibniz was beginning to develop his theory of dynamics; an indication of this is his definition of determination in De affectibus: "Determination is a state from which something does follow [sequitur], provided that nothing else prevents it" (A VI, 4, 1426; translated in Di Bella $(2005,104))$. Thus determination is an inclination, a tendency, conatus. It is also an action in the sense that something follows from its nature. Leibniz illustrates this idea in De Affectibus with an example of a body which falls towards the center of the earth. When the body stops for a moment because of an obstace and then continues falling on the same path (according to a certain physical law) once the obstacle is taken away, then it is very close to spontaneity (A VI, 4, 1428-1429). In other words, its falling follows from its nature spontaneously. One can see here a very early and limited version of a doctrine of substantial forms which Leibniz gave in his Systeme Nouveau of 1695, where he described their source of action as follows: "Aristotle calls them first entelechies; I call them, perhaps more intelligibly, primitive forces, which contain not only act or the completion of possibility, but also an original activity" (Leibniz 1989, 139).

Di Bella has argued that the developing of a serial, abstract and impersonal dimension reflects a distinct Spinozian influence. The series of thoughts is comparable to series of things or series of determinations in the world and the substance unfolds in a kind of logical way (Di Bella 2005, 100-103). ${ }^{29}$ The first affect determines the whole series and its effect lasts until a contrary, stronger affect is encountered. Following Fichant, Di Bella argues that by 1679 Leibniz had already found his basic concept of force and for that reason, he had stopped thinking of bodies as momentary minds and shifted to a dynamical view which makes it possible to form continuous series of thoughts (Di Bella 2005, 103). ${ }^{30}$

While this seems to be a possible reading of De affectibus, it seems to me that there might

\footnotetext{
${ }^{28}$ An interesting comparison can be made to Nouveaux essais II, xxi, $\$ 47$ where Leibniz argues that we cannot affect our moral action directly, but we should reject our bad habits and adopt new ones in order to reach virtue. The habit is in a sense a series of thoughts which can be maintained by strong willing and developing the understanding (A VI, 6, 195-197). See also Roinila (2006) and Jones (2006, 252-261).

${ }^{29} \mathrm{I}$ think Di Bella is right in the sense that in Tractatus de Intellectus Emendatione (1662?), sec. 85 Spinoza argues that an objective effect proceeds in the soul according to the formal nature of its object. Thus the soul acts according to certain laws, like a spiritual automaton. See Spinoza (1985, 37). It is also true that Leibniz continued to use this description of the soul in many of his later writings, for example in Monadologie, $\S 18$. However, he does not use the concept in De affectibus and, as I argue, I think the primary influence can also be Hobbes. See also Monadologie, $\S 37$ and Principes de la nature et de la grace, fondés en raison, $\S 8$.

${ }^{30}$ For Fichant's argument, see Leibniz 1994. For a critical view on Fichant's argument, see Garber (2009b).
} 
be an alternative interpretation. The foremost other influence I can think of is Hobbes. ${ }^{31}$ In De corpore (1655) and De homine (1658) Hobbes had developed a theory of affects where good is strived after, and evil is avoided. These are identified with pleasure and pain and conatus is identified with the beginning of motion (EW I, 406-410). ${ }^{32}$ These definitions provide Leibniz with the basic tools for creating his theory of series of thoughts. In addition, one can find a predecessor to the idea of series of thoughts in Hobbes's "trayne of thoughts" in Leviathan, I, 3 (1651) where he says: "By consequence, or trayne of thoughts, I understand that succession of one thought to another, which is called (to distinguish it from discourse in words) Mentall Discourse" (EW III, 11).

Hobbes regards the train of thoughts a mental discourse of which there are of two kinds. The first is unguided and inconstant wherein there is no passionate thought (for example, dreams). The second kind is more constant and it is regulated by some desire and design (EW III, 12-13). The latter kind of process is remarkably similar to Leibniz's series of thoughts in De affectibus, although Leibniz added will to the picture. The thought is suggested by the understanding and preferred by the will. This opinion is an inclination, a desire, a disposition.

According to De Gaudemar, in 1676 Leibniz strived to replace the Hobbesian conatus with a doctrine of entelechy or primitive power. Thought is seen as action and essences of things consist in a law of acting, analogous to a mathematical series. The primitive power of the mind manifests in its ability to pass through different thoughts without getting stuck in one thought. This ability was enabled by feelings of pleasure or pain to which the will attaches as Leibniz already argued in his 1673 dialogue Confessio philosophi (De Gaudemar 2009, 179). ${ }^{33}$

While it would seem that Leibniz has transferred the Hobbesian conatus from the body to the mind, in De affectibus Leibniz also says that the first affect serves the same role in the soul as impetus in the body. ${ }^{34}$ This leads us to Aristotelianism - in the doctrine of impetus or an impulsion of a body to motion the body is only maintained in motion by the action of a continuous external force (Pasnau 2011, 381-382).

Although I think the influence of Hobbes is prominent in De affectibus, Leibniz introduces an element in the memoir which is distinctly Cartesian or Spinozian. He argues that the series we are thinking can arise either from distinct ideas (of causes, for example) or from confused

\footnotetext{
${ }^{31}$ In this, I am inspired by Goldenbaum's article on Leibniz's early fascination with Hobbes's views (2009, 193196).

${ }^{32}$ Hobbes discusses series of appetites and aversions which form passions such as hope or fear. On Hobbes' views on affects, see also De homine XI, 5 and XIII, 1.

33 See also Goldenbaum $(2009,199)$.

34 “Affectus est in animo, quod impetus in corpore" (A VI, 4, 1426). See also Schepers $(2003,135)$.
} 
ideas when there are many inclinations present at the same time. ${ }^{35}$ This emphasis on confusedness or distinctness of the starting point of a series distances Leibniz from Hobbes and makes one think of Spinoza who, in E3p1d, related affects to the adequacy and inadequacy of ideas (Spinoza 1985, 493-494). Especially this passage in De affectibus would be related to the distinctness or confusedness of the first affects:

We are caused [determinati sumus] to pursue some series of thoughts, either because we are already in it, nor is there a reason for changing; or because we come to a crossroads where many series of thoughts meet, one of them being the strongest of all (A VI, 4, 1434; translated in Di Bella 2005, 102). ${ }^{36}$

The citation exemplifies the mechanical character of the memoir: the mind proceeds like an automaton, one thought following from another, sometimes branching to several related paths or coming to a crossroads where the same thought can lead in several directions (Di Bella $2005,102-103) .^{37}$

However, one can - and I think, should - read De affectibus on a more personal level. In this reading we have to compare the series of thoughts to each other. The idea seems to be that the more distinct the series, the more it involves reality or perfection and the more certainly we continue in the series without being transferred into another series (A VI, 4, $1425,1428 \& 1433)$. For example, if we follow a series of confused thoughts and come across an intersection where a common thought branches into a more distinct series of thoughts, we ought to abandon our present series and follow the more distinct series. The series of thoughts which is initiated by a distinct perception is a clear and recognizable path which is superior to all the concurrent, hardly visible tracks in its vicinity. Leibniz does in fact say that in our initial choice we prefer the series of thoughts which appears to us to be more perfect than other series. In cases where there are intersections, some path is preferred by the will, but the choice is founded on the understanding.

The role of the will is more vague in De affectibus than in Leibniz's later writings, although it is clearly a necessary and independent part of the soul. ${ }^{38}$ We saw that he defined opinion as a volition which follows the understanding, but he does not really present volitions as actions

\footnotetext{
35 "Series cogitandi oritur vel ex ideis distinctis...vel oritur ex ideis confusis" (A VI, 4, 1424-1425). This passage clearly anticipates NE II, xxi, §39.

${ }^{36}$ Although Leibniz does not discuss the topic more extensively, one can easily relate this idea to the classic problem of akrasia or weakness of the will. We are taken by a more vivid thought which leads us to another train of thoughts. The goal, of course, is to turn human attention to the most perfect series. See Leibniz's later discussion of akrasia in NE, II, xxi, §35 (A VI, 6, 185-188).

${ }^{37}$ Of branching, see Blank in this volume, CROSS-REFERENCE

${ }^{38}$ See, for example, Nouveaux essais, II, xxi, §21-30 (A VI, 6, 181-183).
} 
which create new thoughts. Rather, the cause of a thought is another previous thought in the series (Vargas 2011, 178-179). Willing is to be understood here as preferring, inclining to one rather than another initial endeavour. This relates Leibniz to the intellectualism of Thomas Aquinas where the will usually follows the recommendations of the intellect (James 1997, 60-62) and distinguishes him from both Descartes, who emphasized the independence of the will (Losonsky 2001, 12-41), and Hobbes, who thought volition is the last endeavour in deliberation, be it desire or aversion. According to this view, there is no independent criteria of preferring the one to another (EW III, 48-49).

There is no reason to doubt that Leibniz continued to think in the same way as in Confessio philosophi and Elementa verae pietatis that the first affect is a sentiment of good or evil, that is, pleasure or pain. Leibniz understands pleasure or pain as an inclination or a tendency of the mind to pass to another state or thought, or to a train or series of thoughts. ${ }^{39}$ As we saw, Leibniz held to the Aristotelian view that we always strive toward the apparent good. He also agreed with Descartes (and Aristotle) in his later writings that strong willing helps us to act virtuously. $^{40}$

Considering the will as an essential part of the soul distances Leibniz not only from Hobbes, but also from Spinoza. Unlike Descartes, Spinoza thinks that there is no faculty of the will in the mind. He argued that the will is closely related to desire which is conscious striving of the mind and the body and represents conatus (E3p9s). ${ }^{41}$ In itself, will is a thought, identical to an idea and related to the causal chain of substances and subject to its laws. In $D e$ affectibus, the will follows the understanding (A VI, 4, 1412), but is still separated from it. This preferring is nothing like the Spinozian general desire although sometimes Leibniz also discusses the will as a general endeavour which is related to activity and perfection. Compare Nouveaux essais:

Volition is the effort or endeavour [conatus] to move towards what one finds good and away from what one finds bad, the endeavour arising immediately out of one's awareness of those things. This definition has as a corollary in the famous axiom that

\footnotetext{
${ }^{39}$ Giolito compares the Leibnizian affect to Cartesian internal emotions of the soul which he discusses in Passions, §147 (CSM I, 381). These are produced in the soul itself and are therefore not dependent on the movement of the animal spirits, although they may be aroused by external events such as a tragic play. However, the Cartesian intellectual passions are defined as particular passions, while Leibniz's affect is general by nature. See Giolito (1996, 201-202).

${ }^{40}$ See, for example, NE II, xxi, §47. See also Aristotle, Nichomachean Ethics VII.

${ }^{41}$ See also Nadler $(2006,200)$.
} 
from will and power together, action follows; since any endeavour results in action unless it is prevented (NE II, xxi, §5; A VI, 6, 72; Leibniz 1996, 72). ${ }^{42}$

In addition, Leibniz himself commented on Spinoza's views to Oldenbourg in 1675-76, arguing that the will is something essential in the soul, not only a verbal or nominalist way of thinking (De Gaudemar 2009, 185). While in De affectibus the thoughts seem to follow from each other in a sense automatically, the first affect or disposition seems to be essential as it inclines one to perfection or imperfection. For this reason, I think the will is an essential component in the thought series and this distinguishes Leibniz clearly from Spinoza.

Another clear difference is Spinoza's mind-body-parallelism which Leibniz was keen to criticize. In Spinoza's philosophy the mind and the body are attributes of the same substance, God or nature. Both are driven by continuous causal chains which do not directly affect each other and both are produced by God. While Leibniz thought that minds are the forms of bodies, Spinoza argued that the mind is an idea of a body (E3p12; Spinoza 1985, 502). This Leibniz criticized already in De summa rerum of 1676 and in his marginal notes to Spinoza's Opera Posthuma of 1678 (A VI, 4, 1713, n. 21; 1714, n. 22; 1715, n. 28 and 1723, n. 45). As we remember, De affectibus discusses exclusively the mind while Spinoza's theory of affects in Ethica concerns both the mind and the body simultaneously. For these reasons I am inclined to think that Hobbes's theory of affects and the doctrine of trains of thoughts as a mental discourse was a more important influence for Leibniz than Spinoza, although Leibniz's views on deliberation and will are certainly closer to Descartes than to Hobbes.

\section{Perfection, Action and Passion}

We have seen that the first affect starts thought sequences or trains of thought which can rival each other in the sense that the mind may abandon one series and adopt another. While this picture seems to me to be Hobbesian, Leibniz introduces still further element which is Spinozian, namely perfection. In itself, the idea of perfection is not novel in Leibniz's writings. It can be found already in Elementa juris naturalis of 1671, where perceiving pleasure in another person is said to be a sensation of perfection. In Confessio philosophi of

\footnotetext{
${ }^{42}$ Leibniz argues in much the same way in an appendix to Essais de theodicée, titled Remarques sur le livre de l'origine du mal, publié depuis peu en Angleterre: "No agent is capable of acting without being predisposed to what the action demands; and the reasons or inclinations derived from good or evil are the dispositions that enable the soul to decide between various courses...the truth is that the soul, or the thinking substance, understands the reasons and feels the inclinations, and decides according to the predominance of the representations modifying its active force, in order to shape the action." (Leibniz (1978, 416); Leibniz (2005, 421)).
} 
1673 Leibniz was discussing harmony which produces pleasure in the mind. In De affectibus Leibniz says that the soul is determined towards the series of thoughts which in itself is most perfect. ${ }^{43} \mathrm{He}$ also argues that perfection is a degree of reality (A VI, 4, 1429).

In De affectibus Leibniz does not emphasize the metaphysical pluralist framework which is so typical of his writings. But he certainly had it in place long before $1679 .{ }^{44}$ For example, in a dialogue with Steno concerning freedom of 7. December 1677, he wrote: "If all possible series were equally perfect, then it would follow that even one in which all the impious are saved and all the pious are damned would be equally perfect." Therefore it is clear that some series of thought are better than others and he counters the argument by saying that it is contrary to perfection in the sense that it is possible in itself, but carrying it out becomes impossible because it is contrary to God's perfection (Leibniz 2005, 115). ${ }^{45}$

The concept of perfection in De affectibus is also used as a standard of comparison, but from the first-person perspective of the self - one is supposed to enter into a series which appears to be more perfect than other available series. Leibniz does not discuss God's will in the memoir until the very end where an idea of series of a series pops up in connection with spontaneity, which, as we saw, is seen as a natural unfolding of the series (A VI, 4, 1430). An early version of a concept containment theory can also be found in the very end of $D e$ affectibus (A VI, 4, 1441). ${ }^{46}$

The natural unfolding of the series is closely related to action and passion. As we have seen, Leibniz is more interested in actions than passions in the Cartesian sense. ${ }^{47}$ In A VI, 4 , 1428 he defined action as a state of thing to which something follows, arising from its nature. Thus action is related to the new concept of spontaneity, which in Leibniz's philosophy becomes an essential component of freedom (Di Bella 2005, 114-115). ${ }^{48}$ It is also evident that spontaneity is related to distinct perceptions as Leibniz says that the less in following this regress we come across a passive state, the more spontaneous and natural we consider a process (A VI, 4, 1430). We can see that Leibniz is closer here to Spinoza than to either Descartes or Hobbes, as action refers to the substance itself, and not to any kind of

\footnotetext{
43 "Determinatur animus ad eam seriem cogitationum quae in se spectata perfectior est" (A VI, 4, 1430).

${ }^{44}$ On the development of Leibniz's views of harmony, see Mercer $(2001,208-220)$.

${ }^{45}$ Leibniz also argues that the series of things is not necessary by an absolute necessity as there are many other series that are possible, i.e. intelligible, even if they are not actually performed. See Leibniz $(2005,119)$.

${ }^{46}$ See also Di Bella $(2005,127)$.

${ }^{47}$ For Descartes, passions are related to the fundamental difference between the soul and the body. See Passions, §2 (CSM I, 328).

${ }^{48}$ On this topic, see Rutherford \& Cover (2005).
} 
communication between two different kinds of entities. ${ }^{49}$ For Spinoza, going back along the causal chains of the substance leads us to see that the substance is its own dynamical source of action. However, whereas Spinoza sees action as part of the universal law, Leibniz allows the principle of action to each substance of which there is an infinite number. This view, however, is not very prominent in De affectibus.

In addition, Leibniz maintains that determination can be both pure action or mixed with a passion (A VI, 4, 1429). To my mind, this view anticipates a feature essential in Leibniz's later conception of emotions as a ratio of pleasure versus displeasure. In Nouveaux essais II, $\mathrm{xx}, \S 7$ he argues that one can be joyful when tortured (A VI, 6, 166). This marks a substantial difference to Spinoza's view where joy is a transition from lesser perfection to greater perfection. $^{50}$

\section{Conclusion}

De affectibus is an interesting although fragmentary memoir on the philosophy and history of the mind. While the first half of the text is related to Descartes's Les passions de l'âme, in the second half Leibniz drafts a presentation of how the mind works. From the first affect of pleasure or pain, suggested by the understanding and preferred by the will, follows a mental series which continues until an opposite affect is encountered. Each series is independent of the other and therefore they can rival each other. The series can, however, be compared with the standard of perfection. While this view and some other elements in De affectibus seem to be close to Spinoza, I have argued that the basic structure of the doctrine is in place in Leibniz's earlier writings and heavily influenced by Hobbes and Aristotle. I am inclined to think with Martha Kneale that the certain similarities between Spinoza's and Leibniz's views are due to common origin rather than direct influence (Kneale 1976, 236). This common origin is the philosophy of Hobbes.

The view of action and passion presented in De affectibus is related to all of the essential

\footnotetext{
${ }^{49}$ Martha Kneale presents five different definitions on action and passion which she suggest were influenced by reading Spinoza. See Kneale (1976, 220-222).

${ }^{50}$ In Leibniz's mature view, the process of action and passion are atemporal although he sometimes sounds a lot like Spinoza. For example, in NE II, xxi, 72 he says: "If we take 'action' to be an endeavor towards perfection, and 'passion' to be the opposite, then genuine substances are active only when their perceptions... are becoming better developed and more distinct, just as they are passive only when their perceptions are becoming more confused. Consequently, in substances which are capable of pleasure and pain every action is a move towards pleasure, every passion a move towards pain” (A VI, 6, 210; Leibniz (1996, 210)). See also Monadologie $\$ 49$ and Principes de la nature et de la grâce, §3.
} 
components of a Leibnizian metaphysics - what is left for further development after the memoir is the advanced mind-body theory, a mature theory of dynamics and the theory of pre-established harmony. The pre-established harmony is especially important, for in his mature theory of emotions Leibniz argues that the soul is often affected through the passions of the body.

In De affectibus it is left open how the series of thoughts are affected by external objects. The series are rather separate continuums which are occasioned by some pleasure or pain and the change comes only when an opposite series of thoughts is encountered. The theory of expression was already presented in De summa rerum of 1676 , so it is difficult to say why Leibniz does not use it in the memoir instead of discussing it in an apparently Spinozian manner. Perhaps this fact together with his efforts at defining emotions within the framework of series of thoughts suggest that De affectibus was, after all, a draft on emotions rather than on metaphysics. ${ }^{51}$

\section{Bibliography}

Antognazza, Maria Rosa. 2008. Leibniz. An intellectual biography. Cambridge: Cambridge university press.

Boros, Gábor. 2007. Leibniz on love. In The concept of love in 17th and 18th century philosophy, ed. Gábor Boros, Herman De Dijn and Martin Moors, 79-94. Leuven: Leuven university press.

Busche, Hubertus. 2004. Mind and body in the young Leibniz. In Individuals, mind and bodies: themes from Leibniz, ed. M. Carrara, A. M. Nunziante and G. Tomasi, 141-158. Stuttgart: Steiner.

De Gaudemar, Martine. 2009. A few remarks on the Leibnizian conception of the mind in the "early writings" of Leibniz. In The philosophy of the young Leibniz, ed. Mark Kulstad, Mogens Lærke and David Snyder, 177-188. Stuttgart: Steiner.

\footnotetext{
${ }^{51}$ I would like to thank Andreas Blank and an anonymous reviewer for comments to this article. The research for it was made possible by a grant 137891 of the Academy of Finland.
} 
Descartes, René. 1984-1985. The philosophical writings of Descartes, I-II. Trans. John Cottingham, Robert Stoothoff and Dugald Murdoch. Cambridge: Cambridge University Press. (CSM)

Di Bella, Stefano. 2005. The science of the individual: Leibniz's ontology of individual substance. Dordrecht: Springer.

Di Bella, Stefano. 2006. Le De affectibus leibnizien: de la dynamique des passions à la constitution de la substance individuelle. In Les passions à l'âge classique. Theorie et critiques des passions, II, dir. Pierre-François Moreau, 193-208. Paris: Presses universitaires de France.

Garber, Daniel. 1998. Soul and mind: life and thought in the seventeenth century. In The Cambridge history of seventeenth-century philosophy, ed. Daniel Garber and Michael Ayers, 759-795. Cambridge: Cambridge University Press.

Garber, Daniel. 2009a. Leibniz: body, substance, monad. Oxford: Oxford University Press.

Garber, Daniel. 2009b. What did Leibniz learn about body in January 1678? In The philosophy of the young Leibniz, ed. Mark Kulstad, Mogens Lærke and David Snyder, 67-81. Stuttgart: Steiner.

Giolito, Christophe. 1996. L'éradication d'une argumentation cartésienne: Leibniz à la lecture des Passions de l'âme. In Descartes et l'argumentation philosophique, dir. Frédéric Cossutta, 187-216. Paris: Presses universitaires de France.

Goldenbaum, Ursula. 2009. It's love! Leibniz's foundation of natural law as the outcome of his struggle with Hobbes' and Spinoza's naturalism. In The philosophy of the young Leibniz, ed. Mark Kulstad, Mogens Lærke and David Snyder, 189-201. Stuttgart: Steiner.

Hobbes, Thomas. 1839. The English works of Thomas Hobbes of Malmesbury (I \& III), ed. William Molesworth. London: Bohn. (EW)

James, Susan. 1997. Passion and action. The emotions in seventeenth-century philosophy. Oxford: Clarendon Press.

Jones, Matthew L. 2006. The good life in the scientific revolution. Descartes, Pascal, Leibniz and the cultivation of virtue. Chicago: Chicago University Press. 
Kneale, Martha. 1976. Leibniz and Spinoza on Activity. In Leibniz: a collection of critical essays, ed. Harry G. Frankfurt, 215-238. Notre Dame: University of Notre Dame press.

Leibniz, Gottfried Wilhelm. 2005. Confessio philosophi. Papers concerning the problem of evil, 1671-1678. Trans., ed. and with an Intr. Robert C. Sleigh, Jr. New Haven and London: Yale University Press.

Leibniz, Gottfried Wilhelm. 1996. New Essays on Human Understanding, trans. and ed. Peter Remnant and Jonathan Bennett. Cambridge: Cambridge University Press.

Leibniz, Gottfried Wilhelm. 1971. Nouvelles lettres et opuscules inédits. Intr. Louis Alexandre Foucher de Careil. Hildesheim and New York: Olms (1857).

Leibniz, Gottfried Wilhelm. 1989. Philosophical Essays. Edited and Translated by Roger Ariew and Daniel Garber. Indianapolis: Hackett.

Leibniz, Gottfried Wilhelm. 1976. Philosophical papers and letters. A selection trans.and ed., with and intr. Leroy E. Loemker. 2nd ed. Dordrecht: Reidel.

Leibniz, Gottfried Wilhelm. 1978. Die philosophischen Schriften VI, hrsg. C. I. Gerhardt. Olms: Hildesheim.

Leibniz, Gottfried Wilhelm. 1994. La réforme de la dynamique: De corporum concursu (1678) et autres textes inédits, ed. and trans. Michel Fichant. Paris: Vrin.

Leibniz, Gottfried Wilhelm. 1923-. Sämtliche Schriften und Briefe, Reihe I-VII. Herausgegeben von der Berlin-Brandenburgischen Akademie der Wissenschaften und der Akademie der Wissenschaften in Göttingen. Berlin: Akademie Verlag. (A)

Leibniz, Gottfried Wilhelm. 1992. De summa rerum. Metaphysical papers, 1675-1676, trans. with an intr. G. H. R. Parkinson. New Haven and London: Yale university press.

Leibniz, Gottfried Wilhelm. 1985. Theodicy. Essays on the goodness of God, the freedom of man and the origin of evil. Ed. with an intr. Austin Farrer. Trans. E. M. Huggard. La Salle: Open Court (1951).

Losonsky, Michael. 2001. Enlightenment and action from Descartes to Kant. Passionate thought. Cambridge: Cambridge University Press. 
MacDonald Ross, George. 2007. Leibniz's Debt to Hobbes. In Leibniz and the EnglishSpeaking World, ed. by Pauline Phemister and Stuart Brown. Dordrecht: Springer.

Mercer, Christia. 2001. Leibniz's metaphysics. Its origins and development. Cambridge: Cambridge University Press.

Nadler, Steven. 2006. Spinoza's Ethics. An introduction. Cambridge: Cambridge University Press.

Princess Elisabeth of Bohemia and René Descartes. 2007. The correspondence between Princess Elisabeth of Bohemia and René Descartes. Ed. and trans. Lisa Shapiro. Chicago: The University of Chicago Press.

Roinila, Markku. 2006. Deliberation and self-improvement in Leibniz. In Einheit in der Vielheit. VIII. Internationaler Leibniz-Kongress, Vorträge, hrsg. Herbert Breger, Jürgen Herbst and Sven Erdner, 856-863. Hannover: G. W. Leibniz Geschellschaft.

Rutherford, Donald and Cover, J. A. (eds.). 2005. Leibniz. Nature and freedom. Oxford: Oxford university press.

Schepers, Heinrich. 2003. De affectibus. Leibniz an der Schwelle zur Monadologie. Seine Vorarbeiten zum logischen Aufbau der möglichen Welten. Studia Leibnitiana 35: 133-161.

Schneewind, Jerome B. 2006. The active powers. In The Cambridge history of eighteenthcentury philosophy, ed. Knud Haakonssen, 557-607. Cambridge: Cambridge University Press.

Spinoza, Baruch. 1985. The Collected Works of Spinoza, ed. and trans. Edwin Curley. Princeton, NJ: Princeton University Press.

Vargas, Evelyn. 2011. Perceiving machines: Leibniz's teleological approach to perception. In Machines of nature and corporeal substances in Leibniz, ed. Justin E. H. Smith and Ohad Nachtomy, 175-186. Dordrecht: Springer.

Wilson, Catherine. 1997. Motion, sensation, and the infinite: The lasting impression of Hobbes on Leibniz. British journal for the history of philosophy 5: 339-351. 